\title{
Ernesto "Che" Guevara, time and life in Hospital General de México
}

\author{
Alejandro J. García-Delgado ${ }^{1 *}$ and Juan P. Chávez-Pérez ${ }^{2}$ \\ ${ }^{1}$ Geriatrics Service; ${ }^{2}$ Intensive Therapy Service. Hospital General de México “Dr. Eduardo Liceaga," Mexico City, Mexico
}

\begin{abstract}
Ernesto Guevara is a well-known character. Before he participated in various revolutions throughout Latin America, he dedicated his early life and daily work to medicine, his profession, some of which he performed in Hospital General de México.
\end{abstract}

Key words: Ernesto Che Guevara. Physician. Mexico. General Hospital.

\section{Introduction}

Ernesto Guevara de la Serna is one of the most known characters of the last century. Strangely, his medical career is rather forgotten. In a letter to his parents, he wrote:

"In my recollection, I was sorry for not being a better soldier and a better physician; I don't care about the latter anymore, and I'm not doing so bad as a soldier"1.

He carried out some of those medical activities in the Hospital General de México (HGM) where, besides working, he literally lived there in the 50s. There are already many biographies about "el Che"2, his diaries have been published; so, instead of the adventurer, the guerrilla, the dreamer, the symbol or the myth, we'll talk about the relevant details of his being a doctor in the HGM in those years, a workplace and home at the same time.

\section{Brief history}

Ernesto Guevara was born to an aristocratic family on June 14, 1928, in the city of Rosario, Argentina. He studied Medicine in the Buenos Aires National
University from which he graduated by mid-1953. Before that, he worked as an assistant in the Allergy Investigation Institute, led by Dr. Salvador Pisani, where asthma was investigated, a disease Ernesto suffered from since he was a child ${ }^{3}$.

Before consolidating his medical career, he decides to embark himself on a second journey throughout South and Central America. In 1954, he reaches Guatemala, a country with a militia-political revolt that ended up in a coup d'état months after his arrival. In there, he also met Hilda Gadea, a Peruvian woman with whom he had a sentimental relationship. Amidst great chaos, they broke up and then he went to Mexico by September ${ }^{3,4}$.

\section{Life in HGM}

Ernesto Guevara arrived to Mexico in 1954, initially working as a photographer. However, Ernesto was a doctor and had worked in an Allergy Institution in Argentina. it was then that a female Central American doctor introduces Ernesto to Dr. Mario Salazar Mallén, chief of the Allergy Department in HGM. Ernesto is 
accepted as an intern ${ }^{5}$. The director of HGM at that time was Dr. Enrique Flores Espinoza who was dealing with the many economical and staff issues of the hospital. Here's, an anecdote worth telling by Dr. Baltazar Rodríguez Hernández" : "I remember very well the day Dr. Salazar Mallén came to the Allergy Department, accompanied by a young man around 25 years old;... he was introduced to me, $<$ Dr. Ernesto Guevara Serna, recommended by our friend Dr. Pisani...> He was wearing a brown suit. I was told that he would stay with us to learn about the department..."

The young medicine intern asked for and got permission to carry on an investigation protocol, consisting in intradermal injections with digested food extract from patients with food allergies. The results were published in the Revista Iberoamericana de Alergia $7,8,9$. Dr. Guevara tells the following: "Fortunately, I was given food and a home in Hospital General and hopefully a lost coin falls into my nostalgic fingers (I usually spend it like a drunkard on watermelon juice)." Although Dr. Salazar Mallén invited him to live in his house, the young Argentinian intern prefers a sleeping bag over an examination bed in a small consultation room and instruments in the hospital ${ }^{5}$; "his new home."

Dr. Rodríguez continued: "He was an open and kind person to everyone, he would always be disposed to learn. He first learned about the medical cases; then, he participated in the laboratory and in intradermal allergen application, getting to know pollen and fungi..."

"He barely left the hospital, at least in weekdays. Although he had a card allowing him to eat in the doctor's diner, he only ate tortillas and his famous mate tea. Neither of us could afford more; we were poor. We talked about many things, the patients, the laboratory issues and our personal development as doctors, he never mentioned anything about his political affiliation nor the plans that would allow to imagine the things to come."

In HGM, Dr. Guevara comes across Ñico López who he had met in Guatemala and the one who gave him the "Che" nickname, a typical word from Argentina. Ñico got in the Allergy Department with another Cuban $^{10}$. Hilda Gadea also arrived to Mexico, she reunited with Ernesto and they reinitiate the relationship they left between the battles in Guatemala. After a few months of stormy relationship, they decide to live together in May 1955 (although Hilda lived with a girlfriend) and Dr. Guevara moves his belongings to a small apartment in Rhin street, but he spends of his time in HGM.
Around July of the same year, Hilda surprises him with pregnancy.

Dr. Rodríguez Hernández continues to tell: "By mid1955 , we noticed that he was preoccupied. Our coworkers pushed me to find out what was the matter with him and, hermetic at first but ultimately giving up to my insistence, he told me he had a big problem: he wanted to get married but he couldn't do it, given that neither he nor his girlfriend were legal residents. I recalled a friend of mine was the mayor of Tepotzotlán, so I offered to help him. The wedding was prepared in that place and he asked me to be his witness. Before the wedding, he put $\$ 50$ in my pocket so I could go."

A Russian bureaucrat who got to be a close friend of Ernesto remembers a conversation they had in Murmansk (Russia) in the early 60s, "After some chugs of vodka, the Che confessed he married Hilda because she was pregnant. He had too many tequilas, which led him to an absurd gesture of chivalry"11. "The decision of marriage was a very difficult one for me; first, I had to accomplish something for society, and to do that I had to be free." Ernesto told years later. Despite that, the wedding occurred in August 18 of the same year, in Tepotzotlán, State of Mexico; Dr. Baltazar Rodríguez Hernández and Dr. Alberto Martínez Lozano were witnesses. Surprising was the very fact that confirmed Dr. Guevara literally lived in HGM: he wrote "Hospital General" in the address section in his marriage certificate (Fig. 1).

Dr. Baltazar ends up: "He didn't say farewell to anyone when he left. Upon his departure, he said to me one day: Dr. Rodríguez, I invite you to a long journey, you won't need money, it's enough with a bike and a camera to sell photographs. If I got here from Argentina, I can reach further."

He left HGM to formally begin his marital life, he went to live to Nápoles Street \#40, in Juárez suburb. In those days, the Argentinian doctor is introduced to Raúl Castro, a Cuban student leader, who takes him to talk with his brother. In a day of July 1955, Ernesto Guevara meets Fidel Castro. Ernesto tells: "I met him in one of those cold nights in Mexico, and I remember our first conversation was about international politics...;" thus, he discovered the path that would lead him to glory and death. A girlfriend of Fidel and friend of Ernesto tells: "A path solely related to Cuba; the other linked to a scheme of socioeconomic concepts. Without Ernesto Guevara, Fidel Castro would have never become a communist. Without Fidel Castro, maybe Ernesto Guevara would have 


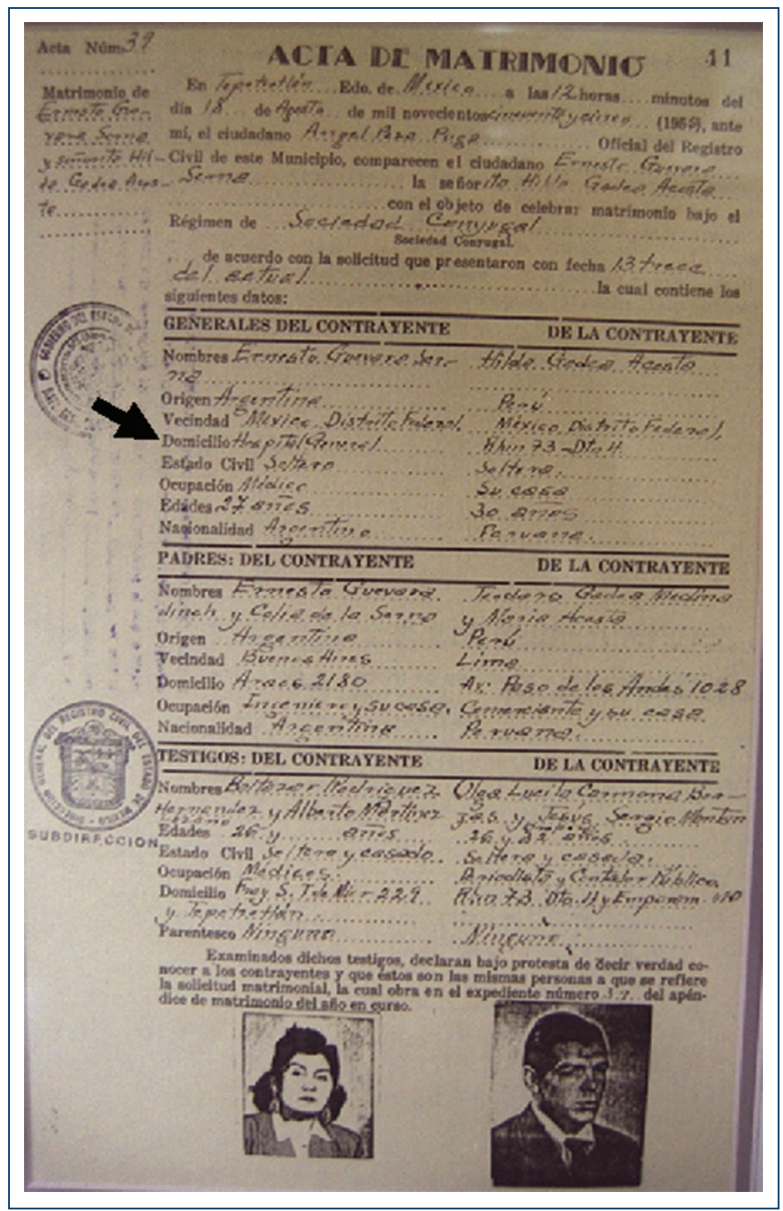

Figure 1. Marriage certificate of Hilda Gadea and Ernesto Guevara. The address box says: General Hospital (Mexico). Today, the Hospital General de México “Dr. Eduardo Liceaga” (arrow). This marriage certificate was stolen from the archives and later returned in a closed envelope with no sender name.

never been more than a Marxist theorist, an idealist intellectual"11,12. Dr. Guevara learns to do haircuts with one of his Cuban exiles and practices his new ability with the patients of the hospital ${ }^{5}$. After a few months of military training, he leaves Mexico aboard the Granma yacht, to the Sierra Maestra, to meet his destiny and become the "Che Guevara" that we all know.

\section{Acknowledgment}

In memory of Dr. Baltazar Rodríguez Hernández, who inspired us to write this article.

\section{Conflicts of interest}

The authors declare that they have no conflicts of interest.

\section{Funding}

The authors are not sponsored to write this article.

\section{Ethical disclosures}

Protection of people and animals. The authors declare that no experiments were performed on humans or animals for this research.

Confidentiality of the data. The authors declare that no patient data appear in this article.

Right to privacy and informed consent. The authors declare that no patient data appear in this article.

\section{References}

1. Ariet MC, Deutschmann D. Che Guevara Presente. New York, EUA: Ocean Press; 2006.

2. Waldman G. La(s) vida(s) de ernesto, el "Che" Guevara: cuatro miradas biográficas y una novela. Lit Lingüística. 2017;36:121-37.

3. El Amaro M. Ernesto Guevara de la Serna, en el aniversario 87 de su natalicio. Rev Cubana Salud Pública. 2015;41:681-3.

4. Steensma D, Shampo M, Kyle R. Ernesto "Che" Guevara de la Serna: argentinian marxist revolutionary. Mayo Clin Proc. 2015;90:111-2.

5. Taibo $P 2^{\text {nd }}$. Ernesto Guevara También Conocido Como el Che. $1^{\text {st }}$ ed. México: Planeta; 1996.

6. Díaz M, Viesca C. Historia del Hospital General de México: 1905-2010. 2nd ed. México: Hospital General de México, Ciudad de México; 2010.

7. Velázquez-Sámano G, Hernández-Solís A, Cicero-Sabido R. El doctor Ernesto Guevara antes de ser el "Che Guevara". Su trabajo en el Hospital General de México. Rev Alerg Mex. 2020;67:196-8.

8. Rodríguez HB. Don mario salazar mallén. Rev Med Hosp Gen. 1997;60:43-4

9. Guevara SE. Pruebas Cutáneas con Extractos de Alimentos Digeridos. Alergia en la Teoría y en la Práctica. México: Editorial Mendez Oteo; 1958. p. 326.

10. Harris R. Che Guevara: a Biography. Greenwood. $1^{\text {st }}$ ed. California: Santa Barbara California; 2011.

11. Castañeda J. La vida en rojo. Una biografía del Che Guevara. México: Alfaguara Primera Edición; 1997.

12. Guevara E. Obras Completas. Argentina: Legasa, Primera Edición; 1996. 